\title{
Research on Influence of Supply Chain Transformation on Economic Benefits of Commercial and Trading Enterprises
}

\author{
Experience and Evidence from Supply Chain Integration*
}

\author{
Hong Zhou \\ School of Financial Management \\ Chongqing College of Electronic Engineering \\ Chongqing, China 401331
}

\begin{abstract}
At present, the development mode of commercial and trading enterprises has transformed from internal integration to external integration. It is an important problem to be solved by commercial and trading enterprises and even the theoretical circle as how to coordinate and cooperate with relevant upstream and downstream enterprises and support them for successful transformation. The economic consequences of companies listed in main board in Shanghai and Shenzhen stock markets are discussed in this paper from the perspective of supply chain integration. It is found through theoretical analysis and empirical inspection that, the economic benefits is improved effectively by the transformation of supply chain of commercial and trading enterprises, and the above economic effect is realized by means of cost reduction, asset turnover rate acceleration, gross marketing profits improvement and rate of return enhancement.
\end{abstract}

Keywords-supply chain integration; commercial and trading enterprise; economic benefit

\section{INTRODUCTION}

The traditional supply chain relationship can no longer fit in with the effective and diverse new business environment with the intensifying market competition and changing customer demand, while strengthening the ability of coordination and cooperation with relevant upstream and downstream enterprises has become the consensus among commercial and trading enterprises. In addition, more and more commercial and trading enterprises start to pay attention to and update their own supply chain mode, striving to optimize resource distribution, promote profit enhancement and push enterprise transformation through supply chain transformation. According to the data published in Investigation Report on Special Topic of Supply Chain Integration in 2017 by a major data website, $88.67 \%$ commercial and trading enterprises consider that the low efficiency of traditional supply chain has restricted the industrial development; $76.44 \%$ investigated commercial and

*This paper is supported by planning project (18SKGH187) of culture and social sciences of Chongqing Education Committee, for which give thanks

CLC No.: F49; F724

Document code: A. trading enterprises are planning to or have started to transform the supply chain; another $74.37 \%$ relevant enterprises regard supply chain integration industry as a hotly contested spot for supply chain transformation and even the market competition among commercial and trading enterprises, which indicate that supply chain integration has become an important push to promote commercial and trading supply chain transformation, and a magic weapon for enterprise transformation and upgrading and healthy industry development.

The essence of supply chain transformation is reflected as forming systematic and integrated supply chain, namely the occurrence of strategic updating behavior for supply chain integration enhancement (Xiao Jinghua, Xie Kang et al., 2015). Viewing from the practice, the supply chain transformation is favored by commercial and trading industry, and some excellent enterprises within the industry, such as Suning Commerce, Yonghui Superstores, Wangfujing and Minmetals Development have also implemented the transformation strategy with supply chain concentration enhancement as the core. However, most commercial and trading enterprises "have much said but little done", "dare not go one step beyond the prescribed limit", and worry about the economic benefits after supply chain reform. Viewing from the theory, the current literatures mainly focus on influential factors of supply chain reform, supply chain reform mode and path, supply chain coordination and other researches, few researches are made based on economic consequence of supply chain transformation from the perspective of supply chain integration, and it is failed to reach consensus for the only literature (Chen Zhenglin, Wang Yu, 2014), so the influence of supply chain integration on economic benefits of commercial and trading enterprises still need to be discussed. The abovementioned condition is taken as a turning point in this paper to discuss and inspect the influence of supply chain integration on economic benefits of commercial and trading enterprises relying on transaction cost theory and dynamic ability theory from the perspective of supply chain integration hoping to provide feasible path for supply chain reform, so as to promote overall transformation upgrading of commercial and trading industry. 


\section{LITERATURE REVIEW AND THEORETICAL ANALYSIS}

\section{A. Literature Review}

With respect to the commercial and trading enterprises, Supply Chain Integration (SCI) is the core of supply chain transformation, and the advanced stage for supply chain optimization and evolution (Flynn et al., 2010), meaning that relevant economic organization coordinates and cooperates with chain members, to promote integration of "four flows", namely the information flow, product flow, service flow and capital flow, through exploration of integrated and systematic supply chain management mode, so that the target created by customer value may be realized (Liu Zhibiao et al., 2009). "Integration" is the essential property of SCI, including organization integration and business integration (Xiao Jinghua, Xie Kang et al., 2015). Among them, organization integration takes supplying and marketing chain as a belt for mutual selection and accurate connection among supplier, producer, consumer, logistics distributor and financial service supplier, so as to build long-term and stable partnership, and enhance the overall coordination efficiency and customer reaction degree. Business integration relies on the main businesses of core enterprises of the supply chain. It eradicates the unnecessary wastes and non-value-added part in the business process completely through constant integration and business optimization, to realize the business intension and mutual benefit among supply chain members. As a result, the SCI has broken the simple economic organization scope, expanded the previous internal integration boundary of commercial and trading enterprises, and become a key of contemporary supply chain transformation (Chen Zhenglin, Wang Yu, 2014).

Viewing from the economic consequence of supply chain integration, part of the literatures investigate the influence of supply chain integration on manufactures, but research consensus is not reached, with few involving the theoretical discussion and empirical inspection of commercial and trading enterprises. On the one hand, some scholars' research results show that, SCI can promote the enterprise economic benefit significantly, for instance, reducing purchase cost (Blaxill et al., 1991), shortening production period (Chen et al., 2004), weakening business risk (Reichhart et al., 2007), strengthening profit ability (Ou et al., 2010); on the other hand, some other literatures refute the abovementioned conclusion, thinking that SCI has little influence on the economic benefits of economic organization and the positive effect of SCI has not been discovered (Stevens, 2004). It is thus clear that the research of supply chain integration's conversion into economic consequence in previous literatures is characterized by "binary opposites". So, which does the supply chain transformation strategy carried out vigorously in China's commercial and trading enterprises in recent years support, "promotion theory" or "irrelevant theory"? It needs to be investigated further, and it is also the problem to be analyzed and inspected in this paper with emphasis.

\section{B. Theoretical Analysis}

The existing theories provide important academic basis and beneficial analysis base for the discussion of economic effect of commercial and trading enterprise supply chain transformation in this paper. (1) Transaction cost theory considers that non-transparent information will cause extra transaction cost to economic organization, which mainly include search cost, information cost, negotiated price cost, decision cost and supervision cost. The implementation of supply chain integrated transformation by commercial and trading enterprises enables it to break the market information bottleneck, change the short-term, blind and fluctuate supplying and marketing relationship with upstream and downstream enterprises, strengthen the coordination and information interaction frequency among various parties of the chain, reduce the expenditure in information search, information change, bargain and negotiation, contract conclusion and subsequent supervision, thus the transaction costs of commercial and trading enterprises in market transaction is reduced, which has provided powerful support for the economic benefit enhancement; (2) Dynamic ability theory points out that, economic organization needs not only the support of heterogeneous resources, but also the dynamic ability promotion to cope with environment change. The reason why commercial and trading enterprises carry out the supply chain integration strategy lies in the acquisition of competitive advantage, so it is bound to involve the integration of product, technology, personnel, funds and other resources as well as the optimization of research innovation, production management, supply chain integration and other dynamic abilities. The abovementioned resource utilization and ability updating process is beneficial to scientific distribution of resources, effective catching of market business opportunity, continuous acquisition of competition ability and full satisfaction of external demand by commercial and trading enterprises, thus to promote rapid increase of wholesale or retail industry, bringing excessive benefits to commercial and trading business.

The basic logic of economic consequence of commercial and trading enterprises after supply chain transformation is put forward in this paper by summarizing the abovementioned transaction cost theory and dynamic ability theory analysis, with theoretical frame as shown in "Fig. 1". First of all, the improvement of integration degree of commercial and trading enterprises will reduce the cost of transaction between them and supply chain members, driving economic benefits from the perspective of "restraining outflow"; second, the supply chain integration reform will intensify commercial and trading enterprises' resource distribution, product supply and customer reaction ability, increasing excessive profits from the perspective of "promoting inflow". As a result, supply chain integration will promote the enhancement of economic benefits of commercial and trading enterprises. 


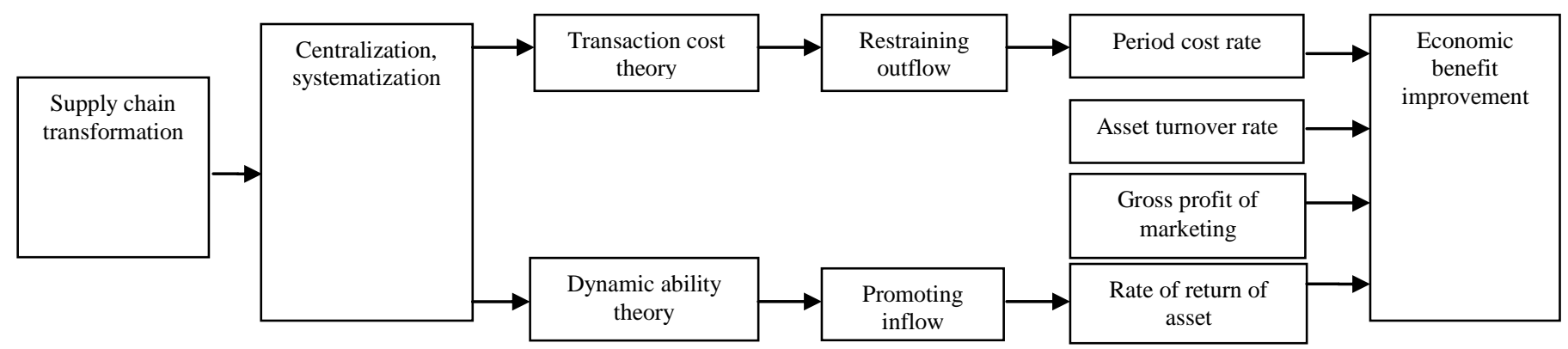

Fig. 1. Frame of economic consequence of commercial and trading enterprises supply chain transformation.

\section{RESEARCH DESIGN}

\section{A. Research Hypothesis}

The significant feature of SCI is "integration of four flows". The commercial and trading enterprises reduce internal and external transaction costs through planning, organization, coordination and controlling of information flow, product flow, service flow and capital flow in the supply chain, to facilitate the enhancement of supply chain efficiency and benefits (Song Hua et al., 2013). It can be said that, the implementation of supply chain transformation with SCI as the superficial characteristics by commercial and trading enterprises, the core member in supply chain, has integrated the resources, abilities, behaviors and activities of many upstream and downstream interested enterprises, which has not only enhanced the operation efficiency and cooperation effect of enterprises at various nodes, but also reduced the unnecessary cost at links of purchase, coordination and logistics. The aforementioned SCI effect is mainly attributed to "Duration Cost" (Chen Zhenglin, 2016). According to Enterprise Accounting Principles, the coordination cost reflects in "management cost", and logistics cost shall be listed in "selling cost". In view of the above, the author proposes the following Hypothesis 1:

Hypothesis 1: Supply chain integration of commercial and trading enterprises can significantly reduce the period cost.

Resource distribution optimization is one of the objectives of commercial and trading enterprises' performing of SCI, and the important reflection of supply chain overall coordination effect. The chain integration of commercial and trading enterprises is advantageous to commercial and trading enterprises for them to establish inter-enterprise corporation, strengthen the mutual trust foundation among supply chain members, promote sharing of supply and marketing information, production technology and technical standard, and to accelerate the turnover of assets relating to survival and development, such as quick assets, fixed assets and intangible assets, thus to promote the improvement of operation efficiency of the whole supply chain. In addition, SCI urges the supply chain members to break the individual enterprise limit, relevant interested units of supply chain are taken into consideration for various decisions and behaviors, the opportunism motivation of upstream and downstream members is gradually replaced by "mutual benefit" (Jiang Wei, 2016), which will strengthen the asset turnover of commercial and trading enterprises and the overall units of the chain. Accordingly, the author puts forward the following Hypothesis 2:

Hypothesis 2: Supply chain integration of commercial and trading enterprises can speed up asset turnover significantly.

Gross profit of marketing is the wind indicator and profit foundation of the marketing condition of economic organization, which attracts much attention from commercial and trading enterprises. Supply chain transformation of commercial and trading enterprises will deepen and expand the external relevant relationship, facilitate the "Interest Binding" among suppliers and distributors and other enterprises, thus to enhance the ability of upstream purchase and material distribution (Blaxill et al., 1991). In addition, commercial and trading enterprises can enjoy discount of supplying partners in the supply chain, to reduce their own purchase cost, weaken sensibility of operating cost, and give play to the gross profit advantage and scale effect. Therefore, the implementation of SCI means commercial and trading enterprises face more favorable purchase environment and price, with more obvious offset effect of purchase cost against the total product cost. In view of the above, the author proposes the following Hypothesis 3:

Hypothesis 3: Supply chain integration of commercial and trading enterprises can improve the gross profit of marketing significantly.

The income from downstream customers is the main profit source of commercial and trading enterprises which is similar to other economic organizations. As for commercial and trading enterprises, they want to transform to "active responder" from "simple supplier" by carrying forward SCI strategy (Shah et al., 2003), make quick reaction against multivariate demand of downstream customers, improve salability and brand reputation of their own products, so as to increase cash inflow (Reichhart et al., 2007). Furthermore, SCI strategy urges the commercial and trading enterprises to focus on the changing end user demand, and the market orientation awareness is increasingly strong along with it. It is conductive to the improvement of supply chain service ability, and brings the abundant remuneration and product dependence. On the basis of the above, the following Hypothesis 4 is put forward in this paper:

Hypothesis 4: Supply chain of commercial and trading enterprises can enhance asset return significantly. 


\section{B. Sample Selection}

In this paper, the period during 2013 to 2016 is taken as research period, the commercial and trading enterprises with obvious supply chain transformation characteristics as research object, and the listed companies of wholesale and retail industries (F) in "two stock markets" which comply with the above industrial characteristics the most as the primary samples for investigation by referring to the industry classification of security supervision committee in 2012. 133 initial samples are obtained through Wind database collection and sorting. The following treatment is made on the basis of the abovementioned: (1) reject the companies "with star or cap"; (2) reject the companies being short of data; (3) reject the companies with significant change in their main business. Further, to avoid the influence of extreme value, the Winsorize treatment is carried out for main variables in this paper.

\section{Variable Design}

The main variables are arranged as shown in "Table I" by referring to the existing achievements and proposed hypothesis, especially the literatures of Wang Yuetang (2006), Song Hua (2013), Chen Zhenglin (2016) and Wang Zhen (2016). The period cost rate, asset turnover rate, gross profit of marketing, rate of return of asset are taken as the substitute interpreted variables for investigating the economic benefit of commercial and trading enterprises, and the better the above indicators, the better the economic benefit of corresponding enterprises; with respect to supply chain integrated SCI, it refers to the mature literature to form the substitute interpretation indicators taking the top five supply and marketing proportions as foundation, and the higher its value, the higher degree of the supply chain integration of commercial and trading enterprises, and vice versa.

TABLE I.

VARIABLE DEFINITION

\begin{tabular}{|c|c|c|c|}
\hline Variables & Variable Code & Methods for Measurement & Literature Index \\
\hline \multicolumn{4}{|l|}{ Dependent variable } \\
\hline Period cost rate & Period Cost Ratio(PCR) & $\begin{array}{l}\text { Sum of management, marketing and financial cost /Operating } \\
\text { income } * 100\end{array}$ & {$[2],[11]$} \\
\hline Asset turnover rate & Total Assets Turnover(TAT) & Operating income / Average value of total assets & {$[9],[11]$} \\
\hline Gross profit of marketing & Gross Profit Margin(GPM) & (Sales income - sales cost) /Sales income $* 100$ & {$[2],[7]$} \\
\hline $\begin{array}{l}\text { Rate of return of asset } \\
\text { Independent variable }\end{array}$ & Return on Total Assets(ROTA) & Net profit /Average value of total asset $* 100$ & {$[5],[7],[9]$} \\
\hline $\begin{array}{l}\text { Supply chain integration } \\
\text { degree }\end{array}$ & SCI & $\begin{array}{l}\text { Ln (Average value of top five supply and marketing } \\
\text { proportion/Variance) }\end{array}$ & {$[3],[9],[12]$} \\
\hline \multicolumn{4}{|c|}{ proporing } \\
\hline Year limit for being listed & Age & Current year - Year of listing & {$[2],[4]$} \\
\hline Nature of the property & Soe & State-owned property is 1 , or it is 0 & {$[4],[9]$} \\
\hline Self-scale & Size & Ln (Total asset) & {$[5],[6]$} \\
\hline Rate of assets and liabilities & Leverage & Total liabilities / Total asset $* 100$ & {$[4],[9]$} \\
\hline $\begin{array}{l}\text { Share hold proportion of } \\
\text { large shareholders }\end{array}$ & Largest & $\begin{array}{l}\text { Number of shares hold by shareholders ranking first / Total } \\
\text { number of shares }\end{array}$ & [2] \\
\hline Board scale & Boardsize & Ln (Number of people of the Board) & {$[9],[10]$} \\
\hline $\begin{array}{l}\text { Proportion of independent } \\
\text { directors }\end{array}$ & Indirecter & $\begin{array}{l}\text { Number of independent directors / Number of people of the } \\
\text { Board }\end{array}$ & {$[9],[10]$} \\
\hline
\end{tabular}

\section{Regression Model}

The design variables are included using multi-element regression model to investigate the influence on economic benefit of commercial and trading enterprises by supply chain integration, with the model as shown below:

$$
\text { Performance }_{\mathrm{i}_{\mathrm{t}} \mathrm{t}}=\beta_{\mathrm{o}}+\beta_{1} \mathrm{SCI}_{\mathrm{i}_{\mathrm{i}} \mathrm{t}}+\beta_{2} \text { Controller }_{\mathrm{i}_{\mathrm{t}} \mathrm{t}}+\varepsilon_{\mathrm{i}, \mathrm{t}}
$$

\section{EMPIRICAL INSPECTION}

\section{A. Descriptive Statistics}

The descriptive statistics of main variables is reported in "Table II". Among them, the average value and mid-value of period cost rate (PCR) are 11.904 and 7.045 respectively, and standard deviation is 8.711 , indicating that the "three kinds of cost" of commercial and trading enterprises are not consistent, namely the economic benefit differs a lot; the average value of asset turnover rate (TAT) is 0.808 , standard deviation is 0.421 , meaning that certain difference exists in asset operation and management efficiency of commercial and trading enterprises; average value and standard deviation of gross profit of marketing (GPM) are 21.013 and 14.245 respectively, indicating that obvious difference still exist in gross profit of different commercial and trading enterprises; the average value of rate of turnover of asset is 4.125 , standard deviation is 5.224, showing that commercial and trading enterprises has quite good overall profit ability, but difference among different units is still very large; the average value and midvalue of supply chain integration degree are 4.738 and 3.135 respectively, indicating that part of the commercial and trading enterprises have carried out supply chain transformation, and the corresponding supply chain concentration degree is at relatively high level.

Moreover, relevance test is conducted in this paper prior to regression analysis, and the result shows that, the relevant coefficient of main variables is below 0.40 , without serious multiple collinear problem, and the relevant degree between independent variable and dependent variable is quite high, without significant deviation from the expectation. 
TABLE II. DEscriptive Statistics OF MAIN VARIABLES

\begin{tabular}{llllll}
\hline Variables & $\begin{array}{c}\text { Average } \\
\text { Value }\end{array}$ & Mid-value & $\begin{array}{c}\text { Standard } \\
\text { Deviation }\end{array}$ & $\begin{array}{c}\text { Max. } \\
\text { Value }\end{array}$ & $\begin{array}{c}\text { Min. } \\
\text { Value }\end{array}$ \\
\hline PCR & 11.904 & 7.045 & 8.711 & 28.410 & 2.433 \\
TAT & 0.808 & 0.686 & 0.421 & 2.864 & 0.416 \\
GPM & 21.013 & 18.699 & 14.245 & 40.115 & 0.920 \\
ROTA & 4.125 & 4.601 & 5.224 & 19.764 & -4.348 \\
SCI & 4.738 & 3.135 & 4.060 & 11.414 & 0.376 \\
Age & 8.055 & 7.000 & 4.227 & 16.000 & 1.000 \\
Soe & 0.431 & 0.000 & 0.419 & 1.000 & 0.000 \\
Size & 7.515 & 5.933 & 0.466 & 9.285 & 4.717 \\
Leverage & 41.384 & 8.219 & 17.610 & 71.341 & 5.401 \\
Largest & 33.412 & 28.714 & 11.065 & 3.694 & 79.318 \\
Boardsize & 2.330 & 2.441 & 0.314 & 3.160 & 1.782 \\
Indirecter & 31.106 & 33.15 & 6.042 & 42.000 & 20.000 \\
\hline
\end{tabular}

\section{B. Regression Analysis}

The multi-element regression result is reported in Table 3, and it can be found that (1) significant negative correlation exists between the supply chain integration degree and period cost rate of commercial and trading enterprises, namely supply chain integration can reduce the period cost significantly; (2) positive correlation exists between supply chain integration degree and rate of turnover of asset when the supply chain integration degree is at level of $1 \%$, showing that supply chain integration can accelerate asset turnover speed significantly; (3) at the level of $1 \%$, positive correlation exist between supply chain integration degree and gross profit of marketing, indicating that the implementation of supply chain transformation by commercial and trading enterprises can strengthen the marketing capability, and enhance the gross profit space; (4) positive correlation exists between supply chain integration degree and rate of turnover of asset at the level of $1 \%$, meaning that the supply chain concentration strategy carried out by commercial and trading enterprises can optimize resource distribution effectively, and strengthen the ability of asset to leverage profit. Generally, the hypothesizes proposed above are all verified, so the supply chain integration of commercial and trading enterprises can enhance their own economic benefits, and is conductive to the cultivation of competitiveness of the whole supply chain, so as to realize the "mutual benefit and win-win effect" among the supply chain members.

TABLE III. MULTI-ELEMENT REGRESSION RESUlT

\begin{tabular}{|c|c|c|c|c|}
\hline Variables & (1)PCR & (2)TAT & (3)GPM & (4)ROTA \\
\hline SCI & $\begin{array}{c}-0.370 * * * \\
(-4.20)\end{array}$ & $\begin{array}{c}0.031 * * * \\
(4.62)\end{array}$ & $\begin{array}{c}0.140 * * * \\
(4.39)\end{array}$ & $\begin{array}{c}0.026 * * * \\
(4.55)\end{array}$ \\
\hline Age & $\begin{array}{c}-0.019 * * * \\
(-5.02)\end{array}$ & $\begin{array}{c}0.108 * * \\
(2.84)\end{array}$ & $\begin{array}{c}-0.113 * * * \\
(4.70)\end{array}$ & $\begin{array}{c}-0.030 * * \\
(-3.07)\end{array}$ \\
\hline Soe & $\begin{array}{c}-0.063^{*} \\
(-2.12)\end{array}$ & $\begin{array}{l}0.007 \\
(0.71)\end{array}$ & $\begin{array}{c}-0.464 * \\
(-2.01)\end{array}$ & $\begin{array}{c}-1.022 * * \\
(-3.94)\end{array}$ \\
\hline Size & $\begin{array}{l}0.062 \\
(0.56)\end{array}$ & $\begin{array}{c}0.043 * * * \\
(4.72)\end{array}$ & $\begin{array}{c}1.136^{* * *} \\
(2.79)\end{array}$ & $\begin{array}{c}1.067 * * * \\
(4.32)\end{array}$ \\
\hline Leverage & $\begin{array}{c}-0.030 * * * \\
(-3.36)\end{array}$ & $\begin{array}{c}0.261 * * * \\
(3.16)\end{array}$ & $\begin{array}{l}-0.469 \\
(-0.24)\end{array}$ & $\begin{array}{c}-0.316 * * \\
(-3.88)\end{array}$ \\
\hline Largest & $\begin{array}{c}-0.016 \text { **** } \\
(-3.01)\end{array}$ & $\begin{array}{c}-0.043 * * * \\
(-2.78)\end{array}$ & $\begin{array}{c}-0.106 * * * \\
(-3.92)\end{array}$ & $\begin{array}{c}-0.095 * * * \\
(-4.18)\end{array}$ \\
\hline Boardsize & $\begin{array}{c}0.215^{* * * *} \\
(2.88)\end{array}$ & $\begin{array}{c}0.357 * * * \\
(4.03)\end{array}$ & $\begin{array}{c}0.533 * * * \\
(3.43)\end{array}$ & $\begin{array}{l}-0.477 \\
(-1.16)\end{array}$ \\
\hline Indirecter & $\begin{array}{c}0.018 * * * \\
(3.44)\end{array}$ & $\begin{array}{l}-0.027 \\
(-1.01)\end{array}$ & $\begin{array}{c}1.704 * * \\
(2.85)\end{array}$ & $\begin{array}{c}0.051 * * * \\
(4.20)\end{array}$ \\
\hline
\end{tabular}

\begin{tabular}{lcccc} 
Variables & $(\mathbf{1}) \mathbf{P C R}$ & $\mathbf{( 2 ) T A T}$ & $\mathbf{( 3 )} \mathbf{G P M}$ & $\mathbf{( 4 ) R O T A}$ \\
\hline Year & Yes & Yes & Yes & Yes \\
Constant & $-11.092^{* *}$ & $3.060^{* * *}$ & -4.616 & $2.643 * *$ \\
& $(-2.87)$ & $(3.95)$ & $(-0.33)$ & $(-2.92)$ \\
$\mathrm{N}$ & 866 & 866 & 866 & 866 \\
$\mathrm{R} 2$ & 0.402 & 0.371 & 0.416 & 0.322 \\
\hline \multicolumn{5}{r}{ a. Note: The numbers in brackets are double-tail T-value. }
\end{tabular}

\section{Steadiness Test}

The following steadiness test is carried out further in this paper to ensure reliability of empirical analysis of the whole article: (1) to solve the internal problem in the empirical analysis, the T-1 phase SCI value re-regression is adopted, and the result is basically consistent with the foregoing; (2) refer to the measurement of enterprise economic benefits by scholars including Song Hua et al. (2013), take net rate of turnover of asset as the dependent variable regression, and SCI is still positive relevant to it at the level of 1\%; (3) refer to the literatures of Melnyk et al. (2004), set dummy variable to measure the supply chain integration of commercial and trading enterprises, and the results are primarily consistent.

\section{CONCLUSION AND SUGGESTIONS}

\section{A. Research Conclusion}

With the intensifying of market competition in commercial and trading industry and deepening adjustment of industrial chain structure, the supply chain transformation has become the effective development path for commercial and trading enterprises to add business value, acquire market competition and reduce transaction cost. The economic consequences of commercial and trading listed companies in Shanghai and Shenzhen stock markets after supply chain transformation is discussed from the perspective of supply chain integration in this paper. It is discovered through theoretical analysis and empirical investigation that, the economic benefits is improved by commercial and trading enterprises through reducing period cost, accelerating asset turnover speed, improving gross profit of marketing, and enhancing the rate of turnover of asset. This conclusion expands the internal integration research of previous supply chain and enriches the literatures about supply chain transformation mechanism and consequences. Furthermore, the research conclusion of this paper also indicates that, the implementation of supply chain transformation with integration as surface features by commercial and trading enterprises is conductive to economic benefit enhancement and effective transformation upgrading, which also has positive practice significance for healthy development of commercial and trading enterprises under new economic environment.

\section{B. Policy Suggestions}

The following policy suggestions are proposed in this paper combining the positive effect of supply chain integration towards the economic benefit of commercial and trading enterprises:

- The supply chain information disclosed by commercial and trading enterprises is of previous value, which can reflect the condition of supply chain transformation and convey positive development 
signal to capital market. As the unit to perform supply chain transformation, commercial and trading enterprises should strengthen the disclosure of supply chain information, especially the disclosure of transaction with upstream supplier, downstream distributor and clients.

- Supply chain integration is conducive to the transaction cost reduction, resource distribution optimization and value chain competitiveness enhancement, especially under the new era background of urgent industrial transaction and limited exploration of enterprise internal potential, supply chain integration provides feasible path for commercial and trading enterprises to obtain competitive advantages continuously. Commercial and trading enterprises should take initiative to devote to supply chain transformation practice, construct the "destiny community" relationship with supply chain member, and promote advantage supplementary, cooperation and win-win effect.

- From the macroscopic view, commercial and trading enterprises are the leader in coping with consumption upgrading and service transaction implementation. With the supply chain integration, it can reduce the conflict in industrial economic operation and promote the upgrading and reform of the whole industrial chain. Supervisory department should support the supply chain integration actions of commercial and trading enterprises vigorously, make efforts to promote its supply and marketing flow improvement, inter-enterprise cooperation enhancement, resource distribution optimization, so as to achieve success transaction in the supply chain and even the whole enterprise.

\section{REFERENCES}

[1] Xiao Jinghua, Xie Kang, Wu Yao, Liao Xuehua. Supply Chain Transformation from Facing Cooperation Partner to Facing Consumer - Research of Double Cases of E-commerce Enterprise Supply Chain [J]. Management World, 2015(04):137-154.

[2] Chen Zhenglin, Wang Yu. Empirical Research on Influence of Supply Chain Integration on Financial Achievement of Listed Company [J]. Accounting Research, 2014(02):49-56.

[3] Flynn, B.B., B.Huo, and X.Zhao. The Impact of Supply Chain Integration on Performance: A Contingency and Configuration Approach[J]. Journal of Operations Management, 2010, 28 (01):58-71.

[4] Liu Zhibiao, Zhang Jie. Empirical Analysis of Export Determination Factors for China's Local Manufacturing Enterprise [J]. Economic Research Journal, 2009, 44(08): 99-112.

[5] Blaxill, M.F., and T.M.Hout. The Fallacy of the Overhead Quick Fix[J].Harvard Business Review, 1991, 69(04): 93-101.

[6] Reichhart A., Holweg M. "Creating the Customer-responsive Supply Chain: a Reconciliation of Concepts"[J].International Journal of Operations \& Production Management, 2007,30(05):1144-1172.

[7] Ou, C.S., F.C.Liu, Y.C.Hung, and D.C.Yen. A Structural Model of Supply Chain Management on Firm Performance[J].International Journal of Operations \& Production Management, 2010, 30 (05):526545.

[8] Stevens, G.C.Integrating The Supply Chain[J].International Journal of Physical Distribution and Materials Management, 2004, 19(08):3-8.
[9] Chen Zhenglin. Customer Concentration, Government Interpretation and Company Risk [J]. Accounting Research, 2016(11):23-29.

[10] Song Hua, Yu Kangkang, Chen Jinliang. Service Supply Chain Operation Mode under Different Circumstances - Multi-case Research of B2B Driven by Resource and Environment [J]. Management World, 2013(02):156-168.

[11] Jiang Wei, Yao Wentao. Implementation of Act on Property Rights and Supply Chain Finance - Experience and Evidence from Accounts Receivable Pledge Mortgage Financing [J]. Economic Research Journal, 2016,51(01):141-154.

[12] Shah R., Ward P.T. "Lean Manufacturing: Context, Practice Bundles and Performance"[J]. Journal of Operations Management, 2003, 2(02): 129-149. 